Dengue ở các đợt dịch trong thời gian nghiên cứu, với type 4 (DENV-4) chiếm tỉ lệ cao nhất và thấp nhất là type 3 (DENV-3.

Bệnh nhân nhiễm type 1 (DENV-1), type 2 (DENV-2), type 3 (DENV-3) và type 4 (DENV-4) chiếm tî lệ lần lượt là $34,01 \%, 19,77 \%, 5,52 \%$ và $40,70 \%$.

\section{TÀI LIÊU THAM KHẢO}

1. Rigau-Pérez JG, Vorndam AV, and Clark GG, The dengue and dengue hemorrhagic fever epidemic in Puerto Rico, 1994-2005. American Journal of Tropical Medicine and Hygiene, 2011. 64: p. $67-74$.

2. Trương Quang Học and cộng sự, Đánh giá các tác động không mong muổn có thể xảy ra khi phóng thả muối Aedes aegypti mang Wolbachia nhằm phòng chống Sốt xuất huyết tại Việt Nam. Dự án Ngăn chặn Sốt xuất huyết tại Việt Nam, 2011: p. 5 - 11.

3. WHO, Update on the Dengue situation in the
Western Pacific Region. Dengue Situation Update Number 467, 2015: p. 5 page.

4. Bộ Y tế, Quyết định 3711 QĐ-BYT ngày 19 tháng 9 năm 2014 của Bô trưởng Bố y tế về việc ban hành "Hướng dẫn giám sát và phòng, chống bệnh sốt xuất huyết Dengue". 2014.

5. Lanciotti R. S., et al., Rapid detection and typing of dengue viruses from clinical samples by using reverse transcriptase-polymerase chain reaction. $]$ Clin Microbiol, 1992. 30(3): p. 545-51.

6. NIHE, Final Report on evaluation of communicable diseases surveillance system in Vietnam 2008. 2009, National Institute of Hygiene and Epidemiology: Hanoi.

7. Thai K. T., et al., Clinical, epidemiological and virological features of Dengue virus infections in Vietnamese patients presenting to primary care facilities with acute undifferentiated fever. J Infect, 2010. 60(3): p. 229-37.

8. Takamatsu Y., et al., A Dengue virus serotype 4dominated outbreak in central Vietnam, 2013. ] Clin Virol, 2015. 66: p. 24-6.

\title{
ĐĂC ĐIỂM LÂM SÀNG VÀ CÁC YẾU TỐ LIÊN QUAN ĐẾN SỞI Có BIẾN CHỨNG Ở TRẺ EM TẠI BỆNH VIỆN NHI ĐÔNGG CẦN THO'
}

\section{TÓM TẮT}

Đặt vấn đề: Sởi là một bệnh truyền nhiễm cấp tính gây ra do virus sởi. Bệnh thường diễn biến lành tính, tuy nhiên tỉ lệ sởi có biến chứng vẫn còn cao. Mục đích của nghiển này nhằm mô tả các đăc điểm lâm sàng và xác định các yếu tố liên quan đến bệnh sởi có biến chứng ở trẻ em. Phương pháp và đối tượng nghiên cứu: Mô tả cắt ngang các trường họp mắc sởi với xét nghiệm Mac-Elisa $\operatorname{IgM}(+)$, nhâp viển tại Bệnh viện Nhi đồng Cần Thơ từ 1/2020 đến 6/2021 Kết quả: Tổng công có 144 trẻ mắc sởi từ 2-60 tháng, tuổi trung vị là 12 tháng, nam chiếm tỉ lệ $58 \%$. Trẻ chưa tiêm chủng sởi chiếm $81,3 \%$. Triêu chứng lâm sàng gồm sốt (100\%), phát ban (100\%), ho $(97,9 \%)$, dấu Koplik $(54,0 \%)$ và nôn ói $(29,2 \%)$. Tỉ lệ sởi có biến chứng là $47,9 \%$. Hai biến chứng hay găp là viêm phổi $(21,5 \%)$ và viêm da dày ruôt $(22,9 \%)$. Các yếu tố có liên quan đến sởi có biển chứng gồm chưa tiêm chủng ( $O R=5,57 ; p=0,022)$, CRP tăng $(\mathrm{OR}=1,08 ; \mathrm{p}=0,027)$ và nôn ói $(\mathrm{OR}=3,05$; $\mathrm{p}=0,036)$. Kết luân: Bệnh sởi thường gặp ở trẻ dưới 12 tháng tuổi, chưa được tiêm chủng. Hai biến chứng hay gặp là viêm phổi và tiêu chảy. Không tiêm chủng, CRP tăng và có nôn ói là các yếu tố có liên quan với bênh sởi có biến chứng.

Tư khóa: Sởi, trẻ em, biến chứng

${ }^{1}$ Trường Đại học Y Dược Cần Thơ

Chịu trách nhiệm chính: Nguyễn Ngọc Rạng

Email: nguyenngocrang@gmail.com

Ngày nhận bài: 16.3.2021

Ngày phản biên khoa hoc: 11.5.2021

Ngày duyệt bài: 18.5.2021
Nguyễn Ngọc Rạng¹, Phan Đặng Trang Đài ${ }^{1}$

SUMMARY

CLINICAL CHARACTERISTICS AND

FACTORS ASSOCIATED WITH MEASLES COMPLICATION IN CHILDREN AT CAN THO CHILDREN'S HOSPITAL

Background: Measles is an acute infectious disease caused by measles virus. The disease usually has a benign course, but measles complications are still high. The aim of this study was to describe the clinical features and identify factors associated with complicated measles in children. Methods and subjects: Cross-sectional description of cases of measles with Mac-Elisa IgM $(+)$, hospitalized at The Can Tho Children's Hospital from 1/2020 to 6/2021 Result: A total of 144 children with measles aged 260 months, median age was 12 months, male accounted for $58 \%$. Unvaccinated children accounted for $81.3 \%$. Clinical symptoms included fever $(100 \%)$, rash $(100 \%)$, cough (97.9\%), Koplik's spot (54.0\%) and vomiting $(29.2 \%)$. Two common complications were pneumonia (21.5\%) and gastroenteritis $(22.9 \%)$. Factors associated with complicated measles included unvaccinated $(\mathrm{OR}=5.57 ; \mathrm{p}=0.022)$, increased CRP (OR=1.08; $p=0.027)$ and vomiting ( $O R=3.05$; $p=0.036)$. Conclusion: Measles was common in unvaccinated children aged under 12 months. Pneumonia and gastroenteritis were 2 common complications. Unvaccinated, elevated CRP, and vomiting were the factors associated with complicated measles.

Keywords: Measles, children, complication

\section{I. ĐĂTT VẤN ĐỀ}

Sởi là một bệnh truyền nhiễm cấp tính gây ra 
do virus sởi thuốc họ Paramyxoviridae, Bệnh sởi chủ yếu ở trẻ em dưới 5 tuổi. Bệnh có biểu hiện đăc trưng là sốt, viêm long và phát ban, có thể dẫn đến nhiều biến chứng như viêm phổi, tiêu chảy, viêm giác mạc, viêm não hoặc thậm chí có thể tử vong.

Ở Việt Nam, tỉ lệ mắc sởi đã giảm rõ rệt nhờ có vắc xin sởi được tiêm phòng rộng rãi, tần suất mắc mới khoảng 116,5/1triệu dân [2]. Tuy vậy, thỉnh thoảng vần có những vụ dịch lớn. Năm 2015, bệnh sởi bùng phát ở Há Nội với 60 nghìn trẻ mắc và 150 trẻ tử vong.. Hầu hết các trường hợp nhập viện gặp ở trẻ dưới 12 tháng tuổi và chưa chủng ngừa[3]. Hiện nay, tử vong do bệnh sởi rất hiếm, tuy nhiên tỉ lệ biến chứng vẫn còn cao trong đó viêm phổi và̀ tiêu chảy là 2 biến chứng thường gặp nhất [4]. Tuổi nhỏ và không tiêm chủng vắc xin sởi là các yếu liên quan đến sởi nặng và có biến chứng [5].

Bểnh sởi trẻ em ở Việt Nam có chiều hướng gia tằng trong những năm gần đây do tỉ lệ tiêm chủng bắt đầu sụt giảm [3]. Tại Cần Thơ, trong 3 tháng đầu năm 2019 đã có 258 trường hợp được chẩn đoán sởi nhập viện. Mục đích của nghiên này nhằm mô tả các đặc điểm lâm sàng và xác định các yếu tố liên quan sởi có biến chứng ở trẻ em tại Bệnh viện Nhi đồng Cần Thơ.

\section{II. ĐỐI TƯỢNG VÀ PHƯƠNG PHÁP NGHIÊN CỨU}

2.1 Thiết kế nghiên cứu: mô tả cắt ngang

2.2. Đối tượng nghiên cứu. Tất cả bệnh nhi được chẩn đoán sởi và điều trị nội trú tại Bệnh viện Nhi Đồng Cần Thơ từ tháng 1 năm 2020 đến tháng 6/2021.

\section{+ Tiêu chuẩn chọn mẫu}

- Tuổi: dưới 5 tuổi.

- Được chẩn đoán mắc sởi dựa trên lâm sàng gồm sốt, phát ban dạng sởi, có triệu chứng viêm long: ho, chảy mũi, viêm kết mạc và dấu Koplik.

Chẩn đoán xác định mắc sởi bằng xét nghiệm Mac-Elisa tìm kháng thể IgM dương tính

+ Tiêu chuân loại trừ

- Trẻ được chẩn đoán đang mắc bệnh viêm phổi, viêm tai giữa, viêm dạ dày ruột, viêm não trước khi có biểu hiện sởi.

- Gia đình bệnh nhân không đồng ý tham gia nghiên cứu

\subsection{Phương pháp thu thập số liệu:}

Một biểu mầu soạn sẵn thu thập các biến về đặc điểm nhân khẩu học, tiền sử tiêm chủng, các triệu chứng và dấu hiệu lâm sàng lúc nhập viện, xét nghiệm đếm tế bào máu toàn bộ, $C$ reactive protein (CRP) và xét nghiệm IgM Macelisa. Viêm phổi được định nghĩa khi có thở nhanh và có dấu hiệu tổn thương phổi trên phim $X$ quang hoặc cấy dịch hô hấp có hiện diện các loại vi khuẩn gây bệnh. Viêm da dày ruột được đinh nghĩa khi có tiêu chảy quá 3 ngày xảy ra sau giai đoạn toàn phát của sởi.

2.4 Xử lý số liệu: Các biến phân loại được trình bày bằng tỉ lệ \%, các biến số được trình bày bằng trung bình (độ lệch chuẩn, ĐLC) hoặc trung vị (khoảng tứ phần vị, KTPV) tùy theo có phân phối chuẩn hoặc không. So sánh các biến phân loại bằng phép kiểm khi bình phương. So sánh các biến số bằng phép kiểm $T$ hoặc MannWhitney tùy theo có phân phối chuẩn hoặc không. Dùng mô hình hồi qui logistic đa biến xác định các biến độc lập có liên quan đến bệnh sởi có biến chứng. Xác định mức có ý nghĩa thống kê khi $p<0,05$. Dùng phần mềm SPSS 22.0 để xử lý số liệu.

\section{KẾT QUẢ NGHIÊN CỨU}

Có tất cả 144 trẻ từ 2-60 tháng tuổi nhập viện được chẩn đoán xác đinh sởi bằng xét nghiệm IgM Elisa. Tuổi trung vị là 12 tháng, trong đó có $38,2 \%$ là trẻ dưới 9 tháng tuổi, đa số $(81,3 \%)$ trẻ chưa đến tuổi tiêm chủng hoặc không tiêm chủng sởi. Có 69 ca có biến chứng, tì lệ có biến chứng là $47,9 \%$. Đặc điểm lâm sàng và biến chứng được trình bày trong bảng 1 .

Bảng 1. Đặc điểm lâm sàng và biên chứng

\begin{tabular}{|c|c|}
\hline Đặc điếm & Số ca (\%) \\
\hline Giới nam $(n, \%)$ & $85(59)$ \\
\hline Tuổi (tháng), trung vi và KTPV & $12(8-22)$ \\
\hline Cân nặng $(\mathrm{kg})$, trung vị và KTPV & $9,5(8,10-11,7)$ \\
\hline $\begin{array}{c}\text { Ngày bệnh trước nhập viện, } \\
\text { trung bình và ĐLC }\end{array}$ & $3,4 \pm 1,3$ \\
\hline $\begin{aligned} \text { Tiêm ngừa: } & \text { Có } \\
& \text { Không }\end{aligned}$ & $\begin{array}{c}27(18,8) \\
117(81,3)\end{array}$ \\
\hline Triệu chứng/dấu hiệu lâm sàng & \\
\hline Sốt & $144(100)$ \\
\hline Phát ban & $144(100)$ \\
\hline Ho & $141(97,9)$ \\
\hline Chảy mũi & $119(82,6)$ \\
\hline Viêm kết mạc mắt & $110(76,1)$ \\
\hline Dấu Koplik & $71(54,9)$ \\
\hline Sưng hạch bạch huyết & $10(6,9)$ \\
\hline Nôn ói & $42(29,2)$ \\
\hline Biến chứng(n=69): Viêm phổi & $31(21,5)$ \\
\hline Viêm dạ dày ruột & $33(22,9)$ \\
\hline Viêm thanh quản & $3(2,1)$ \\
\hline Viêm kết mạc mắt xuất huyết & $1(1,4)$ \\
\hline Viêm loét miệng có mũ & $1(1,4)$ \\
\hline
\end{tabular}

Ghi chú: KTPV: khoảng tứ phân vị, ĐLC: độ lệch chuẩn 
So sánh giữa lâm sàng và xét nghiệm giữa nhóm có và không có biến chứng được trình bày trong bảng 2.

Bảng 2. So sánh lâm sàng và xét nghiệm giữa 2 nhóm có và không có biên chứng

\begin{tabular}{|c|c|c|c|}
\hline Các biến & $\begin{array}{l}\text { Có biến chứng } \\
(n=69)\end{array}$ & $\begin{array}{c}\text { Không biến chứng } \\
(n=75)\end{array}$ & Giá trị p \\
\hline Giới nam $(n, \%)$ & $46(54,1)$ & $23(39,0)$ & 0,074 \\
\hline Tuối (tháng), trung vị (KTPV) & $9(7-15)$ & $14(9-36)$ & $<0,001$ \\
\hline Có chúng ngưaa & $5(7,2)$ & $22(29,3)$ & 0,001 \\
\hline $\mathrm{Ho}$ & $67(97,1)$ & $74(98,6)$ & 0,551 \\
\hline Viêm kết mạc & $55(84,6)$ & $55(73,3)$ & 0,368 \\
\hline Chảy mũi & $58(84,0)$ & $61(81,3)$ & 0,666 \\
\hline Sưng hạch bạch huyết & $5(7,2)$ & $5(6,6)$ & 0,811 \\
\hline Dấu Koplik & $41(63,1)$ & $38(50,6)$ & 0,292 \\
\hline Nôn ói & $29(30,4)$ & $13(17,3)$ & 0,001 \\
\hline Hemoglobin & $11,4 \pm 1,1$ & $11,6 \pm 1,4$ & 0,320 \\
\hline Bạch câu $\left(x 10^{9} / \mathrm{L}\right)$ & $9,2 \pm 3,7$ & $7,7 \pm 3,4$ & 0,011 \\
\hline Tiếu câu $\left(\times 10^{9} / \mathrm{L}\right)$ & $320 \pm 81$ & $290 \pm 101$ & 0,061 \\
\hline C-reative Protein $(\mathrm{mg} / \mathrm{L})$ & $8,1(2,8-15,8)$ & $4,5(2,8-9,1)$ & 0,035 \\
\hline Ngày nằm viện, trung bình (SD) & $9,9 \pm 3,7$ & $7,4 \pm 2,0$ & $<0,001$ \\
\hline
\end{tabular}

Nhận xét: So sánh với nhóm không có biến chứng, nhóm sởi có biến chứng có tuổi nhỏ hơn $(<0,001)$, không tiêm chủng $(p=0,001)$, có triệu chứng nôn ói $(p=0,001)$, bạch cầu cao $(p=0,011)$ và $\operatorname{CRP}$ tăng $(0,035)$. Nhóm có biến chứng có ngày nằm viện dài hơn $(p<0,001)$.

Dùng mô hình hồi qui logistic phân tích đa biến nhận thấy có 3 biến độc lấp có liên quan đến sởi có biến chứng gồm không tiêm chủng sởi, có triệu chứng nôn ói và CRP tăng (bảng 3 )

Bảng 3. Các yếu tồ liên quan đến biên chứng trong phân tích đa biến

\begin{tabular}{|c|c|c|c|}
\hline Các biến & $\begin{array}{c}\text { Hê̂ số } \\
\text { hối qui }\end{array}$ & $\begin{array}{c}\text { OR (KTC } \\
\mathbf{9 5 \%} \%\end{array}$ & $\mathbf{P}$ \\
\hline Tuổi & 0,015 & $\begin{array}{c}0,98 \\
(0,95-1,02)\end{array}$ & 0,402 \\
\hline Giới & 0,462 & $\begin{array}{c}1,58 \\
(0,63-3,99)\end{array}$ & 0,326 \\
\hline $\begin{array}{c}\text { Tiêm } \\
\text { chủng sởi }\end{array}$ & 1,719 & $\begin{array}{c}5,57 \\
(1,28-24,2)\end{array}$ & 0,022 \\
\hline Nôn ói & 1,117 & $\begin{array}{c}3,05 \\
(1,07-8,68)\end{array}$ & 0,036 \\
\hline $\begin{array}{c}\text { C-Reactive } \\
\text { Protein }\end{array}$ & 0,081 & $\begin{array}{c}1,08 \\
(1,00-1,18)\end{array}$ & 0,027 \\
\hline
\end{tabular}

\section{BÀN LUÂ̂N}

Trong thời gian nghiên cứu chúng tôi ghi nhân được 144 trẻ dưới 5 tuổi, nhập viện được chẩn đoán xác định sởi bằng xét nghiệm IgM Mac-Elisa. Đa số các trường hợp nhập viện thường có triệu chứng nặng hoặc có biến chứng. Các trường hợp nhẹ được khám tại phòng khám ngoại trú hoặc các phòng khám tư, điêu này chứng tỏ bệnh sởi vần còn khá phổ biến và có thể gây thành dịch do việc xao lãng tiêm chủng vắc-xin sởi. Tuổi mắc sởi của nghiên cứu chúng tôi thấp (trung vị 12 tháng tuổi) so với nghiên cứu của tác giả Phạm Thu Hà và Đỗ Văn Dũng tại Thành phố Hồ Chí Minh là 6,8 tuổi [1], cũng thấp hơn báo cáo của Gianniki và cộng sự [6] trong vụ dịch sởi tại Ai Cập năm 2017-2018 có trung vị là 36 tháng tuổi. Trong nghiên cứu này có $38,4 \%$ trẻ dưới 9 tháng tuổi, điêu này có thể là do kháng thể bảo vệ từ mẹ giảm nhanh sau sinh.Theo nghiên cứu của Javed và cộng sự (CS) [7] tại Pakistan nhận thấy chỉ có $24 \%$ trẻ dưới 9 tháng tuổi có đủ mức kháng thể (nồng độ $>12$ $\mathrm{U} / \mathrm{ml}$ ) để bảo vệ. Vì vậy có nên tiêm chủng vắc xin sởi cho trẻ sớm hớn 9 tháng tuổi để giảm tî lệ mắc sởi?

Nghiên cứu này nhận thấy tất cả triệu chứng và dấu hiệu lâm sàng của bệnh sởi như sốt, phát ban, ho, chảy mũi, viêm kết mạc cũng tương tự như báo cáo của tác giả khác $[1,6]$, riêng dấu Koplik $(54,7 \%)$ có tỉ lệ cao hơn báo cáo khác tại Việt $\operatorname{Nam}(38,0 \%)$ [1] và tại Ai cập $(16,6 \%)$ [6]. Viểm phổi $(21,5 \%)$ và viêm dạ dày ruột $(22,9 \%)$ là hai biến chứng hay găp nhất trong bênh sởi. Tỉ lệ biến chứng này cũng tương tự như báo cáo của Phạm Thu Hà và CS tại TP Hồ Chí Minh [1], tuy nhiên thấp hơn nhiêu so với báo cáo của Kondova và CS [8] tại Macedonia với tỉ lệ biến chứng viêm phổi và tiêu chảy lần lượt là 79,93\% và 40,08\%. Chúng tôi không ghi nhận biến chứng viêm não trong đoàn hệ này.

Tiêm chủng sởi không những giảm tỉ lệ mắc bệnh sởi mà còn làm giảm độ nặng hoặc sởi có biến chứng [9]. Nghiên cứu vụ dịch sởi trẻ em ở Macedonia, Kondova và CS nhận thây hầu hết $(92,6 \%)$ trẻ không được tiêm chủng sởi, do vậy tỉ lệ biến chứng viêm phổi và tiêu chảy rất cao. 
Ngoài ra CRP cao, một dấu ấn của viêm phổi bội nhiễm cũng tăng. Gianniki và CS [6] nhận thấy $38 \%$ trẻ mắc sới có biến chứng có CRP trong máu cao $(>20 \mathrm{mg} / \mathrm{L})$ so với $14 \%$ ở trẻ mắc sởi không biến chứng $(p<0,001)$. Trong nghiên cứu chúng tôi không tiêm chủng sởi và CRP máu tăng là hai yếu tố liên quan đến sởi có biến chứng. Ngoài ra các trẻ mắc sởi nhập viện có nôn ói cũng là một yếu tố độc lập có liên quan đến sởi có biến chứng.

Giới hạn của nghiên cứu này là nghiên cứu hồi cứu tại một bệnh viện nên không phản ảnh toàn thể các ca mắc sởi tại thành phố Cần Thơ, hơn nữa số trường hợp được làm xét nghiệm IgM không nhiều, tuy nhiên nghiên cứu này cho thấy hầu hết các trường hợp sởi có biến chứng đều ở những trẻ chưa được tiêm chủng sởi.

\section{KẾT LUÂN}

Trong nghiên cứu của chúng tôi bệnh sởi thường xảy ra ở trẻ nhỏ dưới 12 tháng tuổi, đa số chưa được chủng ngừa sởi. Các triệu chứng và dấu hiệu lâm sàng hay gặp gồm sốt $(100 \%)$, phát ban $(100 \%)$, dấu Koplik $(57 \%)$, ho, chảy mũi, viêm kết mạc và nôn ói. Biến chứng thường gặp nhất là viêm phổi $(21,5 \%)$ và viêm dạ dày ruột $(22,9)$. Không tiêm chủng, CRP trong máu tăng và có triệu chứng nôn ói là các yếu tố độc lập có liên quan đến bệnh sởi có biến chứng.

TÀI LIỆU THAM KHẢO
1. Phạm Thị Thu Hà và Đỗ Văn Dũng (2004), Đăc điểm lâm sàng bệnh sởi ở trẻ em TP Hồ Chí Minh sau khi thức hiện chương trình tiêm chủng mở rộng, Tạp chí Y học TP. Hồ Chí Minh, 8(1), tr. 6-8.

2. Do ĹP, Van TTT, Nguyen DTM, et al. (2021) Epidemiological and molecular characteristics of a measles outbreak in northern Vietnam, 2013-2014. J Clin Virol;139:104840.

3. Kien VD, Van Minh H, Giang KB, et al (2017) Trends in childhood measles vaccination highlight socioeconomic inequalities in Vietnam. Int J Public Health. 62(Suppl 1):41-49.

4. Marufu $T$, Siziya $S$, Murugasampillay $S$, et al. (1997). Measles complications: the importance of their management in reducing mortality attributed to measles. Cent Afr J Med.;43(6):162-5.

5. Marufu T, Siziya S, Tshimanga M, et al. (2001) Factors associated with measles complications in Gweru, Zimbabwe. East Afr Med J.;78(3):135-8.

6. Gianniki $M$, Siahanidou $T$, Botsa $E$, et al. (2018) Measles epidemic in pediatric population in Greece during 2017-2018: Epidemiological, clinical characteristics and outcomes. PLoS One. 6(1):e0245512.

7. Javed N, Saqib MAN, Hassan Bullo MM, et al. (2019) Seroprevalence of transplacentally acquired Measles antibodies in unvaccinated infants at nine months of age and its relation to the feeding practices. BMC Infect Dis.;19(1):587.

8. Kondova IT, Milenkovic Z, Marinkovic SP, et al. (2013) Measles outbreak in Macedonia: epidemiological, clinical and laboratory findings and identification of susceptible cohorts. PLOS One.; 8(9):e74754.

9. Cherry JD, Zahn M. (2018) Clinical Characteristics of Measles in Previously Vaccinated and Unvaccinated Patients in California. Clin Infect Dis.; 67(9):1315-1319.

\section{NĂNG LỰC QUẢN LÝ CỦA CÁC ĐIỀU DƯỡNG TRƯởNG KHOA LÂM SÀNG CỦA MộT SỐ BỆNH VIÊ̂N CÔNG LÂPP TUYẾN TỈNH LÀO CAI, 2020}

\section{Nguyễn Ngọc Bích ${ }^{1}$, Lù Tà Phìn ${ }^{2}$}

\section{TÓM TẮT}

Năng lực quản lý của điều dưỡng trưởng là một yếu tố quan trọng để tận dụng mọi nguồn lực tại khọa và bệnh viện để phục vụ và chăm sóc người bệnh. Nghiển cứu mô tả nắng lực quản lý của điêuu dưỡng trưởng các khoa lâm tại các bệnh viện công lập tuyến tỉnh Lào Cai được triển khai năm 2020.Thiết kể nghiên cứu cắt ngang thực hiện tại 05 Bệnh viện tuyến tỉnh của tỉnh Lào Cai từ tháng $6 / 2020-11 / 2020$. Số liệu định lượng thu thập từ bộ câu hỏi phát vấn 54 cán bộ y tế là điêu dưỡng trưởng các khoa lâm sàng, năng

\section{${ }^{1}$ Trường Đại học Y tế công cộng}

²Bênh viện đa khoa tỉnh Lào Cai

Chịu trách nhiệm chính: Nguyễn Ngọc Bích

Email: nnb@huph.edu.vn

Ngày nhận bài: 17.5 .2021

Ngày phản biên khoa họ: 12.5 .2021

Ngày duyệt bài: 18.5 .2021 lực quản lý được đánh giá dựa trên mức đô tư tin khi thực hiện công việc, nghiên cứu cũng đã tiến hành phỏng vấn sâu trển các điều dưỡng trưởng.Kết quả nghiên cứu cho thấy Tỷ lệ điều dưỡng trưởng khoa đủ năng lực quản lý chung vẫn ở mức trung bình là $57,4 \%$. Nghiên cứu khuyến nghị cần tiếp tục đào tạo bồi dưỡng về kiến thức và kỹ năng quản lý điểu dưỡng đồng thời có các hình thức giám sát hỗ trợ.

Tư khoá: quản lý, năng lực, điêuu dưỡng trưởng, bệnh viện

\section{SUMMARY \\ MANAGEMENT CAPACITY OF CHIEF NURSES AT SOME PROVINCIAL HOSPITAL IN LAO CAI, 2020}

Management capacity is one of the most important features in maximizing hospital resources toward good services for patients. This study was conducted in 2020 to investigate the situation of knowledge $s$ on 